\title{
Ecogenesis of organs and tissues formation of in cattle in the embryonic period
}

\author{
Nikolay Fenchenko ${ }^{1}$, Nazira Hairullina ${ }^{1}$, Albina Aminova ${ }^{1,{ }^{*}}$, Munir Sabitov ${ }^{1}$ and Fanus \\ Shagaliev ${ }^{1}$ \\ ${ }^{1}$ Bashkir State Agrarian Institute, 19, Rihard Zorge St., 450059, Ufa, Russia
}

\begin{abstract}
The article gives a comparative aspect of the organism development periodization, depending on the gender and age of the fetus. It was established that in the individual development of animals, there is a specific biological regularity of periodicity. It is indicated by the unequal growth of individual organs and the organism as a whole at different stages of ontogenesis, age-related features in the growth of individual parts and proportions of the body, as well as changes in the requirements of a growing organism to living conditions. At different stages of animal embryogenesis, there is a rather short period of a sharp increase in metabolism, as well as the intensity and usefulness of self-renewal, which to some extent, is an indicator of the growth rate of the fetus depending on gender. Pituitary and serum gonadotropins were used to induce ovulation of cows. As a result, in the group where pituitary gonadotropin was used, $87.5 \%$ of cows with pregnancy of $91.7 \%$ showed desire, $75 \%$ of serum gonadotropin with $87.5 \%$ of pregnancy. An analysis of the obtained data shows that in the second stage of embryonic development, the intensity of the formation of internal organs slows down, while the intensity of increasing the live weight of the fetus increases, regardless of groups.
\end{abstract}

\section{Introduction}

One of the essential reserves for intensifying the reproduction of cattle is hormonal regulation of the reproductive function of cows [1]. Artificial insemination provides a real opportunity to fertilize up to 50 thousand and more cows and heifers with the semen of one bull per year. Meanwhile, the cow is slightly inferior to the male in reproductive potential [2]. The number of primary follicles in the ovaries of cows and heifers from which the embryo can be obtained ranges from 100 thousand to 1 million and remains unchanged from 2 months of age to 8-10 years, after which it slowly decreases. Due to artificial hormonal stimulation, it is possible to cause the growth of not one but several follicles and the number of embryos per donor can increase from 50 to 70 per year [3].

It is known that the body, being in close connection with environmental conditions and participating in a constant metabolism with various external and internal factors, does not remain constant. Starting with the formation of a zygote, in its development it goes through a series of periods strictly following one after another [4]. The body requires certain living

\footnotetext{
${ }^{*}$ Corresponding author: albina_ufa@list.ru
} 
conditions to pass each of them [5;6]. Based on this, it follows that the study of the rhythmicity of the growth and development of embryos will contribute to a deeper understanding of the laws of their formation and the further cultivation of highly productive and viable breeding animals $[7 ; 8 ; 9]$.

Despite the high modern level of diagnosis of various conditions of animals, as well as laboratory objects, it is not always possible to study the rhythmic growth and development of the fetus as accurately as possible, therefore the preparation method allows more accurate assessment of the fetus $[10 ; 11 ; 12]$.

The processes of growth and development of the embryo and fetus in cows are determined by the morphofunctional fullness of the germ cells involved in fertilization and are regulated by the nature of maternal nutrition, the state of metabolic homeostasis and the genital organs of the mother $[13 ; 14]$.

Our research was based on the goal of finding out, in a comparative aspect, the periodization of the development of the organism depending on gender, fetal age, and biologically active compounds in the form of FSH ( follicle-stimulating hormone) - super and PMSG (pregnant mare serum gonadotropin) gonadotropins for induced ovulation of cows; and with these indicators, to determine the features of the rhythmic growth and development of cattle.

\section{Materials and Methods}

In the agricultural enterprise "Geroi" collective farm of the Chekmagush district of the Republic of Bashkortostan a study was conducted on breeding cows of black-motley breed after calving (30-40 days) to stimulate reproductive function. The animals of the first experimental group were injected with serum gonadotropin PMSG in a dose of $3000 \mathrm{IU}$, the second experimental group - pituitary gonadotropin FSH-super at 100 IE. The cows of the control group came to desire naturally. Then, the cows of all groups were implanted with embryos. The groups were selected depending on the period of pregnancy according to the principle of analogues, three heads in each group in the amount of 72 heads of female and male individuals. The animals of the three groups were in the same conditions of feeding and keeping. The effectiveness of the drug in the experimental groups was evaluated by the number of animals that came to the desire and became pregnant.

With different periods of pregnancy from 2 to 9 months of age, organs and tissues were prepared, followed by individually weighing each of them according to the method of G. Schmidt (1965).

\section{Results}

Table 1. The effectiveness of various hormonal treatment regimens by animal groups.

\begin{tabular}{|c|c|c|c|}
\hline \multicolumn{1}{|c|}{ Indicator } & Control group & $\begin{array}{c}\text { 1 experimental group } \\
\text { (PMSG) }\end{array}$ & $\begin{array}{c}\text { 2 experimental group } \\
\text { (FSH-super) }\end{array}$ \\
\hline Number of cows, $\mathrm{n}$ & 24 & 24 & 24 \\
\hline Came to desire, $\mathrm{n}-\%$ & $16-67$ & $18-75$ & $21-87.5$ \\
\hline Pregnancy, $\mathrm{n}-\%$ & $19-79.2$ & $21-87.5$ & $22-91.7$ \\
\hline
\end{tabular}

In the second experimental group, desire was shown by $87.5 \%$ of cows with a pregnancy of $91.7 \%$, in the first experimental group - $75 \%$ with a pregnancy of $87.5 \%$. In the control group, cows naturally came to desire in an amount of $67 \%$, followed by a pregnancy of $79.2 \%$ (Table 1). The research results proved that the effectiveness of serum gonadotropin (PMSG) is lower than when using pituitary (FSH-super) relative to the quantitative indicators of induced desire and pregnancy, while with the cows of the control 
group without stimulation of reproductive function the effectiveness is slightly less than of experimental ones.

In the next part of the study, the preparation of the fetuses was carried out in the same groups and it was established that a certain regularity of periodicity is observed in the individual development of animals, as indicated by the unequal growth of individual organs and the body as a whole at different stages of ontogenesis, age-related features in the growth of individual parts and body proportions, as well as changes in the requirements of a growing organism to living conditions in the uterine period.

In experiments on black and white cattle, we found that depending on gender and age, as well as biologically active compounds in the form of FSH-super and PMSG gonadotropins for induced ovulation of cows, a fairly clear periodization of the development of the organism is observed. So, the duration of the periods in the fetuses, depending on gender, was different. Moreover, in the fetal period, the intensity of the development of male fetuses was noted, which is probably due to the process of restructuring the status of animals taking into account their gender.

Also, the use of hormonal treatment of cows with various gonadotropins, from which embryos were then obtained in the initial stage of embryogenesis, significantly influenced the weight of the fetus over periods of ontogenesis. Moreover, the superiority in increasing the weight of the fetus depending on gender and age in the groups was not the same.

At different stages of animal embryogenesis, there is a rather short period of a sharp increase in metabolism, as well as the intensity and usefulness of self-renewal, which to some extent is an indicator of the growth rate of the fetus depending on gender (Table 2).

Table 2. Dynamics of live weight of fetuses in ontogenesis, g.

\begin{tabular}{|c|c|c|c|c|c|c|c|c|c|}
\hline \multirow{2}{*}{$\begin{array}{c}\text { Indi } \\
\text { cato } \\
\text { r }\end{array}$} & \multirow{2}{*}{ Group } & \multicolumn{8}{|c|}{ Age, months } \\
\hline & & 2 & 3 & 4 & 5 & 6 & 7 & 8 & 9 \\
\hline \multirow{3}{*}{$\begin{array}{l}\text { Fem } \\
\text { ale } \\
\text { fetus }\end{array}$} & Control & $\begin{array}{c}6.24 \pm \\
0.11 \\
\end{array}$ & $\begin{array}{c}218.0 \pm \\
0.19\end{array}$ & $\begin{array}{c}1.22 \pm \\
0.21\end{array}$ & $\begin{array}{c}6.08 \pm \\
0.83\end{array}$ & $\begin{array}{c}10.21 \pm \\
1.21\end{array}$ & $\begin{array}{c}21.13 \pm \\
3.28\end{array}$ & $\begin{array}{c}23.42 \pm \\
2.28\end{array}$ & $\begin{array}{c}28.35 \pm \\
5.31\end{array}$ \\
\hline & $\begin{array}{l}\text { Experi } \\
\text { mental } \\
1 \\
\text { (PMSG }\end{array}$ & $\begin{array}{c}7.01 \pm \\
0.22 * *\end{array}$ & $\begin{array}{l}224.5 \pm \\
0.21 * *\end{array}$ & $\begin{array}{c}1.31 \pm \\
0.26^{* *}\end{array}$ & $\begin{array}{c}6.32 \pm \\
0.77^{* *}\end{array}$ & $\begin{array}{c}10.42 \pm \\
1.28^{*}\end{array}$ & $\begin{array}{c}21.91 \pm \\
4.17\end{array}$ & $\begin{array}{c}23.87 \pm \\
2.71^{*}\end{array}$ & $\begin{array}{c}29.92 \pm \\
6.12 *\end{array}$ \\
\hline & $\begin{array}{l}\text { Experi } \\
\text { mental } \\
2 \\
\text { (FSH- } \\
\text { super) }\end{array}$ & $\begin{array}{l}6.83 \pm \\
0.18^{*}\end{array}$ & $\begin{array}{c}220.3 \pm \\
0.28\end{array}$ & $\begin{array}{c}1.28 \pm \\
0.25\end{array}$ & $\begin{array}{c}6.26 \pm \\
0.89\end{array}$ & $\begin{array}{l}10.89 \pm \\
1.17^{* *}\end{array}$ & $\begin{array}{l}22.17 \pm \\
3.87 * *\end{array}$ & $\begin{array}{c}24.11 \pm \\
2.94^{*}\end{array}$ & $\begin{array}{l}30.52 \pm \\
6.24 * *\end{array}$ \\
\hline \multirow{3}{*}{$\begin{array}{l}\text { Male } \\
\text { fetus }\end{array}$} & Control & $\begin{array}{c}7.53 \pm \\
0.18\end{array}$ & $\begin{array}{c}237.4 \pm \\
0.17\end{array}$ & $\begin{array}{c}1.36 \pm \\
0.18\end{array}$ & $\begin{array}{c}6.43 \pm \\
0.72\end{array}$ & $\begin{array}{c}11.14 \pm \\
1.42\end{array}$ & $\begin{array}{c}22.31 \pm \\
4.42\end{array}$ & $\begin{array}{c}24.56 \pm \\
3.17\end{array}$ & $\begin{array}{c}31.17 \pm \\
5.73\end{array}$ \\
\hline & $\begin{array}{l}\text { Experi } \\
\text { mental } \\
1 \\
\text { (PMSG } \\
\text { ) }\end{array}$ & $\begin{array}{l}7.91 \pm \\
0.20^{*}\end{array}$ & $\begin{array}{c}244.9 \pm \\
0.28^{*}\end{array}$ & $\begin{array}{c}1.39 \pm \\
0.23^{* *}\end{array}$ & $\begin{array}{c}6.78 \pm \\
0.83^{* *}\end{array}$ & $\begin{array}{l}11.62 \pm \\
1.38^{* *}\end{array}$ & $\begin{array}{l}23.42 \pm \\
3.96^{* *}\end{array}$ & $\begin{array}{c}25.13 \pm \\
3.51^{*}\end{array}$ & $\begin{array}{c}32.02 \pm \\
5.02\end{array}$ \\
\hline & $\begin{array}{l}\text { Experi } \\
\text { mental } \\
2 \\
\text { (FSH- } \\
\text { super) }\end{array}$ & $\begin{array}{c}8.17 \pm \\
0.31 * *\end{array}$ & $\begin{array}{l}252.5 \pm \\
0.34 * *\end{array}$ & $\begin{array}{c}1.45 \pm \\
0.26^{* *}\end{array}$ & $\begin{array}{c}7.13 \pm \\
0.96^{* *}\end{array}$ & $\begin{array}{l}12.02 \pm \\
1.29 * *\end{array}$ & $\begin{array}{l}23.89 \pm \\
4.21^{* *}\end{array}$ & $\begin{array}{l}26.87 \pm \\
4.18^{* *}\end{array}$ & $\begin{array}{c}32.82 \pm \\
6.32\end{array}$ \\
\hline
\end{tabular}

Where: * $\mathrm{P}<0.5 ; * * \mathrm{P}<0.05$.

As can be seen from the data obtained in female fetuses, the use of hormonal treatment 
with pituitary gonadotropin in animals had a positive effect on the formation of the fetus in the womb [15]. In particular, the superiority of the experimental group 2 where this drug was used in comparison with the control group $0.77 \mathrm{~g}$ or $12.34 \%$ at two months of age, 6.5 $\mathrm{g}(2.98 \%)$ at three months of age, and $0.09 \mathrm{~g}$ at four months of age $(7.38 \%)$ and five months of age $-0.24 \mathrm{~g}(3.95 \%)$ with a significant difference $(\mathrm{P}<0.05)$. Moreover, the highest absolute growth rates were between the control and the second experimental group, where previously they used the hormone FSH-super in their mothers.

Meanwhile, the difference in favor of the second experimental group in comparison with the control group was $0.68 \mathrm{~g}$ or $6.66 \%$ at the age of six months, $1.04 \mathrm{~g}(4.92 \%)$ at the seven-month age, and $0.69 \mathrm{~g}(2.95 \%$ at the eight-month age $)$, nine months of age $-2.17 \mathrm{~g}$ $(7.65 \%)$. However, relatively low indicators of live weight were observed in the female fetuses of the first experimental group in this age period: $0.21 \mathrm{~g}(2.06 \%), 0.78 \mathrm{~g}(3.69 \%)$, $0.45 \mathrm{~g}(1.92 \%) 0.57 \mathrm{~g}(2.01 \%)$, respectively.

The analysis of the obtained data shows that the representatives of the second experimental group, where FSH-super gonadotropin was used for hormonal treatment of cows, were characterized by the highest live weight indicators in male fetuses. In particular, the superiority between the control and the second experimental group was $0.64 \mathrm{~g}$ or $8.49 \%$ at the two-month age, $15.1 \mathrm{~g}(6.36 \%)$ at the three-month age, and $0.09 \mathrm{~g}(6.62 \%)$ at the four-month age, five months - $0.7 \mathrm{~g}(10.89 \%)$, six months - $0.88 \mathrm{~g}(7.89 \%)$, seven months $1.58 \mathrm{~g}(7.08 \%)$, eight months - $2.31 \mathrm{~g}(9.41 \%)$, nine-month - $1.65 \mathrm{~g}(5.29 \%)$, respectively.

Meanwhile, the fetuses of males of the first experimental group were characterized by a slightly lower intensity of development of live weight in comparison with the control one. In particular, the difference between these groups at the age of 2-9 months was: $0.38 \mathrm{~g}$ (5.05\%), $7.5 \mathrm{~g}$ (3.16\%), $0.03 \mathrm{~g}(2.21 \%), 0.35 \mathrm{~g}$ (5.44\%), $0.48 \mathrm{~g}(4.31 \%), 1.11 \mathrm{~g}(4.98 \%)$, $0.57 \mathrm{~g}(2.32 \%), 0.85 \mathrm{~g}(2.73 \%)$ respectively.

As can be seen, there was a clear pattern of uneven development of the fetus, its organs and tissues in ontogenesis, which is expressed both in reducing and increasing the intensity of growth, the formation of individual organs and tissues of animals. A significant role in the duration of growth and development in the embryonic period belongs, along with the organism as a whole, to the development of individual organs and tissues. However, the analysis of the data shows that the organs and tissues of the fetus of the experimental groups developed most intensively (Tables 3, 4).

During the formation period, fully formed head, limbs, skin, internal organs, including the liver, heart, lungs, kidneys, and gastrointestinal tract are clearly manifested. However, their weight depended little on gender and ranged slightly from $0.03-0.08 \mathrm{~g}$ to $1.02-1.19 \mathrm{~g}$ in the female fetuses and 0.01-0.08 $\mathrm{g}$ to $1.23-1,53 \mathrm{~g}$ in the male fetuses.

Meanwhile, the development of the head, trunk, front and hind limbs, skin, liver, heart, lungs, kidneys, and gastrointestinal tract in the female fetuses of the experimental groups was most clearly manifested (Table 3 ). In particular, the superiority was in individuals of the 2nd and 3rd experimental groups and in comparison with the control group at three months old: $2.41-8.8 \mathrm{~g}$ or $7.49-29.59 \%, 0.43-0,97 \mathrm{~g}(4.85-10.95 \%), 0.35-0.80 \mathrm{~g}(3.89-$ $8.89 \%), 0.76-1.83 \mathrm{~g}(6.82-16.43 \%), 0.16-0.40 \mathrm{~g}(2.03-5.08 \%), 0.38-0.71 \mathrm{~g}(2.71-5.07 \%)$, $0.46-1.13 \mathrm{~g}(19,17-47.08 \%), 0.29-0.41 \mathrm{~g}(5.06-7.16 \%), 0.24-0.65 \mathrm{~g}(18.05-48.87 \%), 0.41-$ $1.18 \mathrm{~g}(4.68-13.47 \%)$; four months of age: $11.3-22.2 \mathrm{~g}(3.79-7.73 \%), 6.5-18.4 \mathrm{~g}(1.48-$ 4.19\%), 1.8-6.4 g (3.42-12.59\%), 1.4-6.9 g (1.77-8.75\%), 3.7-10.4 g (12.29-34.55\%), 7, 6$16.1 \mathrm{~g}(23.31-49.39 \%), 03-0.5 \mathrm{~g}(3.29-5.49 \%), 1.4-3.3 \mathrm{~g}(2.78-6.75 \%), 0.5-1.1 \mathrm{~g}(35.55-$ $80.88 \%), 3.9-6.8 \mathrm{~g}(4.29-7.49 \%)$, respectively.

In the following months of embryonic development, organs and tissues in approximately the same rhythm increased mass, and with different intensities. A particularly significant increase in the mass of development of organs and tissues, regardless of groups, was at five, six, and seven months of fetal development. In particular, 
twofold superiority was observed in the experimental groups in comparison with the control group. Meanwhile, the difference in the size of the female fetuses in favor of 2,3 experimental groups was 65.7-106.3 g (11.27-18.23\%), 0.08-0.17 g (6, 61-14.04\%), 0.13$0.27 \mathrm{~g}(8.44-17.53 \%)$, trunk $23.1-34.9 \mathrm{~g}$ (8.41-12.71\%), $0.27-0.40 \mathrm{~g}(5.30-8.36 \%), 0.24-$ $0.56 \mathrm{~g}(3.29-6.86 \%)$, front and hind limbs 11.9-18.5 g (3, 16-4.92\%), 0.04-0.06 g (9.09$13.63 \%), 0.11-0.16 \mathrm{~g}(10.68-15.53 \%)$ and $23.8-50.2 \mathrm{~g}(5.54-11.69 \%), 0.06-0.10 \mathrm{~g}(6.82-$ $11.36 \%), 0.07-0.2 \mathrm{~g}(3.59-10.26 \%)$, skin $28.4-63.1 \mathrm{~g}(12.43-27.61 \%), 0.05-0.09 \mathrm{~g}$ (7.94$14.29 \%)$, 0.17-0.3 g (6.94-12.24\%), liver, heart, lungs, kidneys and gastrointestinal tract 23.9-30.6 g (23.32-29.85\%), 0.04-0.07 g (23.53-41.18\%), 0.03-0.11 g (6.0-22.0\%), 1.4-3.7 $\mathrm{g}(5.86-15.48 \%), 0,03-0.05 \mathrm{~g}(23.08-38.46 \%), 0.02-0.04 \mathrm{~g}(10.0-20.0 \%), 3.3-4.9 \mathrm{~g}(3.41-$ $5.25 \%), 0.01-0.03 \mathrm{~g}(6.25-18.75 \%), 0.09-0.12 \mathrm{~g}(15.52-20.69 \%), 3.6-6.8 \mathrm{~g}(5.13-9,70 \%)$, $0.07-0.18 \mathrm{~g}(9.21-23.68 \%), 0.17-0.19 \mathrm{~g}(18.68-20.88 \%), 24.6-54.1 \mathrm{~g}(4.61-10.14 \%), 0.11-$ $0.17 \mathrm{~g}(18.03-27.87 \%), 0.18-0.26 \mathrm{~g}(19.15-27.66 \%)$, respectively .

In the final stage of the embryonic period, in eight- and nine-month-old female fetuses of the experimental groups, in comparison with the control group, a noticeable increase in head mass by $0.13-0.54 \mathrm{~g}(6.98-24.32 \%)$, respectively, of the body $0.43-2.04 \mathrm{~g}(5.39$ $22.32 \%)$, front and hind limbs $0.11-0.65 \mathrm{~g}(4.60-26.86 \%)$ and $0.12-0.65 \mathrm{~g}(3.65-26.86 \%)$, skin $0.09-0.33 \mathrm{~g}(3.13-10.38 \%$ ), as well as internal organs such as the liver $0.06-0.25 \mathrm{~g}$ (8.22-26, 59\%), heart 0.06-0.12 g (28.0-48.0\%), lungs 0.07-0.19 g (6.25-26.39\%), kidney $0.15-045 \mathrm{~g}(8.29-36.29 \%)$, of the gastrointestinal tract $0.03-0.47 \mathrm{~g}(1.59-3.59 \%)$. The process of development of these organs and tissues in the female fetuses occurred with slightly lower intensity (Table 3).

The maximum increase in three-month-old male fetuses was noted in comparison with two-month-old ones: by head mass, a 29-32-fold increase, torso - 28-49, fore and hind limbs - 56-139 (Table 4).

Meanwhile, at four, five months, a slightly different pattern of development of such internal organs as the liver, heart, lungs and kidneys appeared. In particular, an increase in organs was noted in the fetuses of the experimental groups in comparison with the control liver 0.9-2.0 g (1.80-4.01\%), 21.6-42.1 g (15.73-30 66\%); heart 0.8-1.4 g (8.26-12.84\%), 2.2-4.4 g (7.77-15.55\%); light 2.6-5.9 g (4.83-10.97\%), 18.4-23.8 g (18.19-23.54\%); kidneys $1.1-2.3 \mathrm{~g}(7.28-15.23 \%), 4.2-11.1 \mathrm{~g}(5.35-14.14 \%)$; the gastrointestinal tract 1.8 $4.2 \mathrm{~g}(1.79-4.17 \%), 56.2-102.3 \mathrm{~g}(9.33-16.98 \%)$, respectively.

Nevertheless, at the age of six months, the male fetuses of the experimental groups showed a slight increase in organs in comparison with the same organs of the fetuses of the control group. The difference in favor of the 2nd and 3rd experimental groups was 0.07$0.12 \mathrm{~g}(4.96-8.51 \%)$ by head weight, $0.13-0.45 \mathrm{~g}$ of the body $(2.46-8.52 \%)$, front and hind limbs $0.07-0.11 \mathrm{~g}(13.46-21.15 \%), 0.19-0.32 \mathrm{~g}$ (18.63-31.37\%), skin 0.08-0, $12 \mathrm{~g}$ (10.53$15.79 \%)$, internal organs: liver $0.05-0.09 \mathrm{~g}$ (18.52-33.33\%), heart 0.02-0.04 g (12.5$25.0 \%$ ), lungs $0.08-0.15 \mathrm{~g}$ (38.09-71.43\%), kidneys $0.12-0.13$ g (12.37-13.40\%), gastrointestinal tract $0.19-0.32 \mathrm{~g}(23.75-40.0 \%)$, respectively.

A similar pattern was observed at the age of seven months.

A more intensive development was observed in eight- and nine-month-old fetuses and amounted to $0.22-0.46 \mathrm{~g}(10.43-21.80 \%), 0.11-0.35 \mathrm{~g}(3.89-12.37 \mathrm{~g})$ by weight of the head $\%$, torso $0.21-0.34 \mathrm{~g}(2.41-3.89 \%), 1.16-2.36 \mathrm{~g}(10.26-20.87 \%)$, front and hind limbs 0.19 $0.42 \mathrm{~g}(6.15-13.5 \%), 0.11-0.22 \mathrm{~g}(2.98-6.09 \%)$, skin $0.19-0.37 \mathrm{~g}(6.15-11,97 \%), 0.12-0.17$ $\mathrm{g}(3.36-4.76 \%)$ and internal organs: liver $0.08-0.16 \mathrm{~g}(9.30-18.60 \%), 0.16-0.23 \mathrm{~g}(13.22-$ 19.01\%), hearts 0.04-0.14 g (10.26-35.89\%), 0.03-0.05 g (5.36-8, 93\%), lungs 0.14-0.21 g (14.29-21.43\%), 0.06-0.13 g (4.96-10.74\%), kidneys 0.33-0, 36 g (21.15-23.08\%), 0.02$0.08 \mathrm{~g}(0.98-3.92 \%)$, gastrointestinal tract $0.42-0.69 \mathrm{~g}(36.84-60,53 \%), 0.11-0.19 \mathrm{~g}(5.45-$ $9.41 \%)$, respectively. 


\section{Conclusions}

Based on the study, it was found that the effectiveness of serum gonadotropin is slightly lower than when using the pituitary, but at the same time, the development of organs and tissues with a fairly high intensity up to eight and nine months of age was observed in the fetuses of both experimental groups compared to the control. It has been established that in the second stage of embryonic development, the intensity of the formation of internal organs slows down, while the intensity of increasing the live weight of the fetus increases, regardless of groups.

Thus, in order to grow a full-fledged well-developed pedigree young animals, it is necessary to carry out hormonal stimulation of cows with FSH-super and PMSG gonadotropins 30-40 days after calving, since during this period the most important organs and tissues, such as the head, liver, heart, lungs, gastrointestinal tract are laid and begin their development.

\section{References}

1. A. Aminova, A. Kolesnik, Reproduction in Domestic Animals 54(3), 84 (2019)

2. A. Pankratova, A. Aminova, S. Kozyrev, Al-Azawi Nagham, Plant Archives 19, 24-30 (2019)

3. L. Valadão, H. Moreira da Silva, F. Moreira da Silva, Embryology - Theory and Practice, IntechOpen, DOI: 10.5772/intechopen.80655

4. P.R. Adona, P.S. Monzani, S. Guemra, M.S. Miranda, O.M. Ohashi, UNOPAR Científica. Ciências Biológicas e da Saúde 15(3), 245-250 (2012)

5. I. Gordon, Laboratory Production of Cattle Embryos. 2nd ed. (Cabi Publishing, Washington, 2013)

6. C.B. Walser, H.D. Lipshitz, Current Opinion in Genetics and Development 21, 431443 (2011)

7. L. Minyuk, K. Portnova, A. Yanshina, Age of Science 10, 104-107 (2017)

8. A. Nezhdanov, V. Mikhalev, G. Chusova, N. Papin, A. Chernitsky, E. Lozova, Agricultural Biology 51(2), 230-237 (2016)

9. A. Chernitsky, S. Shabunin, V. Safonov, Agricultural biology 54(2), 246-258 (2019)

10. L. Teltsov, V. Stolyarov, I. Music, V. Temlyakova, Morphology 153(3), 269-270 (2018)

11. J. Kanka, L. Nemcova, T. Toralova, K. Vodickova-Kepkova, P. Vodicka, M. Jeseta, et al., Animal Reproduction Science 134(1-2), 29-35 (2012)

12. M. Binelli, W.W. Thatcher, R. Mattos, P.S. Baruselli, Theriogenology 6, 1451-1463 (2015)

13. K.L. Moore, T.V.N. Persaud, Embriologia básica. 5th ed. (Guanabara Koogan, Sãn Paulo-Brasil, 2010)

14. H. Bai, T. Sakurai, J.D. Godkin, K. Imakawa, Journal of Reproduction and Development 59(1), 1-6 (2013)

15. F. De Rensis, F. López-Gatius, I. García-Ispierto, M. Techakumpu, Theriogenology 73(8), 1001-1008 (2010) 
Table 3. The dynamics of the development of the body, internal organs and tissues of the female fetuses in ontogenesis, $g$

\begin{tabular}{|c|c|c|c|c|c|c|c|c|c|c|c|}
\hline $\begin{array}{l}\text { Fetus } \\
\text { age, } \\
\text { months }\end{array}$ & Group & Head & Torso & Forelimbs & Hind limbs & Skin & Liver & Heart & Lungs & Kidneys & $\begin{array}{l}\text { Gastrointestinal } \\
\text { tract }\end{array}$ \\
\hline \multirow[b]{2}{*}{2} & control & $1.02 \pm 0.04$ & $0.18 \pm 0.08$ & $0.12 \pm 0.03$ & $0.08 \pm 0.01$ & $0.14 \pm 0.03$ & $0.23 \pm 0.03$ & & $0.03 \pm 0.01$ & & \\
\hline & experimental 1 & $1.14 \pm 0.05$ & $0.26 \pm 0.04$ & $0.15 \pm 0.06$ & $0.15 \pm 0.03$ & $0.20 \pm 0.07$ & $0.31 \pm 0.04$ & & $0.06 \pm 0.01$ & & \\
\hline \multirow{3}{*}{3} & control & $29.73 \pm 1.83$ & $8.86 \pm 2.38$ & $8.99 \pm 0.98$ & $11.14 \pm 1.12$ & $7.87 \pm 0.89$ & $14.01 \pm 0.97$ & $2.40 \pm 0.57$ & $5.73 \pm 0.87$ & $1.33 \pm 0.24$ & $8.76 \pm 0.87$ \\
\hline & experimental 1 & $32.14 \pm 1.97$ & $9.29 \pm 0.92$ & $9.34 \pm 0.86$ & $12.21 \pm 0.93$ & $8.03 \pm 0.93$ & $14.39 \pm 0.88$ & $3.53 \pm 0.42$ & $6.02 \pm 0.93$ & $1.57 \pm 0.27$ & $9.17 \pm 0.92$ \\
\hline & experimental 2 & $38.53 \pm 1.92$ & $9.83 \pm 3.14$ & $9.79 \pm 0.99$ & $12.97 \pm 1.03$ & $8.27 \pm 0.91$ & $14.72 \pm 0.92$ & $2.86 \pm 0.51$ & $6.14 \pm 0.88$ & $1.98 \pm 0.29$ & $9.94 \pm 0.96$ \\
\hline \multirow{2}{*}{4} & control & $287.2 \pm 7.38$ & $438.2 \pm 9.73$ & $50.8 \pm 1.32$ & $78.9 \pm 0.89$ & $30.1 \pm 1.21$ & $32.6 \pm 1.56$ & $9.1 \pm 0.89$ & $48.9 \pm 1.48$ & $13.6 \pm 0.96$ & $90.8 \pm 1.25$ \\
\hline & experimental 2 & $309.4 \pm 4.28$ & $456.6 \pm 8.37$ & $57.2 \pm 1.17$ & $85.8 \pm 0.98$ & $40.5 \pm 1.51$ & $48.7 \pm 1.95$ & $9.6 \pm 0.98$ & $52.2 \pm 1.77$ & $14.7 \pm 0.77$ & $97.6 \pm 1.57$ \\
\hline \multirow{3}{*}{5} & control & $583.1 \pm 2.37$ & $274.5 \pm 3.12$ & $376.3 \pm 4.23$ & $429.4 \pm 5.41$ & $228.5 \pm 2.37$ & $102.5 \pm 4.57$ & $23.9 \pm 0.84$ & $93.4 \pm 1.08$ & $70.1 \pm 0.89$ & $533.6 \pm 1.21$ \\
\hline & experimental 1 & $648.8 \pm 2.91$ & $297.6 \pm 3.78$ & $388.2 \pm 4.09$ & $453.2 \pm 5.89$ & $256.9 \pm 2.45$ & $126.4 \pm 5.23$ & $25.3 \pm 0.97$ & $96.7 \pm 1.04$ & $73.7 \pm 0.95$ & $558.2 \pm 1.37$ \\
\hline & experimental 2 & $689.4 \pm 2.86$ & $309.4 \pm 2.07$ & $394.8 \pm 5.54$ & $479.6 \pm 6.12$ & $291.6 \pm 2.81$ & $133.1 \pm 5.11$ & $27.6 \pm 0.82$ & $98.3 \pm 0.96$ & $76.9 \pm 0.89$ & $587.7 \pm 1.29$ \\
\hline \multirow{3}{*}{$6^{*}$} & control & $1.21 \pm 0.32$ & $4.82 \pm 0.89$ & $0.44 \pm 0.06$ & $0.88 \pm 0.04$ & $0.63 \pm 0.07$ & $0.17 \pm 0.01$ & $0.13 \pm 0.06$ & $0.16 \pm 0.08$ & $0.76 \pm 0.08$ & $0.61 \pm 0.07$ \\
\hline & experimental 1 & $1.29 \pm 0.37$ & $5.09 \pm 0.74$ & $0.48 \pm 0.05$ & $0.94 \pm 0.05$ & $0.68 \pm 0.09$ & $0.21 \pm 0.02$ & $0.16 \pm 0.05$ & $0.17 \pm 0.09$ & $0.83 \pm 0.08$ & $0.72 \pm 0.09$ \\
\hline & experimental 2 & $1.38 \pm 0.28$ & $5.22 \pm 0.87$ & $0.50 \pm 0.04$ & $0.98 \pm 0.03$ & $0.72 \pm 0.14$ & $0.24 \pm 0.03$ & $0.18 \pm 0.03$ & $0.19 \pm 0.04$ & $0.94 \pm 0.08$ & $0.78 \pm 0.06$ \\
\hline \multirow[b]{2}{*}{7} & control & $1.54 \pm 0.18$ & $7.29 \pm 1.09$ & $1.03 \pm 0.32$ & $1.95 \pm 0.27$ & $2.45 \pm 0.16$ & $0.50 \pm 0.22$ & $0.20 \pm 0.16$ & $0.58 \pm 0.21$ & $0.91 \pm 0.23$ & $0.94 \pm 0.29$ \\
\hline & experimental 1 & $1.67 \pm 0.13$ & $7.53 \pm 1.14$ & $1.14 \pm 0.12$ & $2.02 \pm 0.17$ & $2.62 \pm 0.21$ & $0.53 \pm 0.14$ & $0.22 \pm 0.12$ & $0.67 \pm 0.19$ & $1.08 \pm 0.27$ & $1.12 \pm 0.31$ \\
\hline \multirow[t]{2}{*}{8} & experimental 1 & $1.99 \pm 0.27$ & $8.41 \pm 1.13$ & $1.72 \pm 0.27$ & $2.78 \pm 0.39$ & $2.97 \pm 0.41$ & $0.73 \pm 0.08$ & $0.32 \pm 0.09$ & $0.84 \pm 0.15$ & $1.51 \pm 0.27$ & $1.67 \pm 0.37$ \\
\hline & experimental 2 & $2.09 \pm 0.21$ & $8.67 \pm 1.07$ & $2.02 \pm 0.17$ & $3.1 \pm 0.15$ & $3.05 \pm 0.21$ & $0.82 \pm 0.14$ & $0.37 \pm 0.15$ & $0.91 \pm 0.23$ & $1.69 \pm 0.18$ & $1.78 \pm 0.54$ \\
\hline \multirow{3}{*}{9} & control & $2.22 \pm 0.49$ & $9.14 \pm 1.15$ & $2.28 \pm 0.64$ & $3.29 \pm 0.37$ & $3.18 \pm 0.52$ & $0.94 \pm 0.08$ & $0.42 \pm 0.19$ & $1.12 \pm 0.82$ & $1.81 \pm 0.52$ & $1.88 \pm 0.31$ \\
\hline & experimental 1 & $2.47 \pm 0.53$ & $10.22 \pm 1.16$ & $2.39 \pm 0.48$ & $3.41 \pm 0.49$ & $3.34 \pm 0.43$ & $1.01 \pm 0.17$ & $0.49 \pm 0.11$ & $1.19 \pm 0.73$ & $1.96 \pm 0.68$ & $1.99 \pm 0.18$ \\
\hline & experimental 2 & $2.76 \pm 0.36$ & $11.18 \pm 2.13$ & $2.61 \pm 0.37$ & $3.74 \pm 0.56$ & $3.51 \pm 0.83$ & $1.19 \pm 0.19$ & $0.53 \pm 0.09$ & $1.22 \pm 0.79$ & $2.09 \pm 0.43$ & $2.02 \pm 0.35$ \\
\hline
\end{tabular}

* starting at 6 months of age in $\mathrm{kg}$ 
Table 4. The dynamics of the development of the body, internal organs and tissues of male fetuses in ontogenesis, $g$

\begin{tabular}{|c|c|c|c|c|c|c|c|c|c|c|c|}
\hline $\begin{array}{l}\text { Fetus } \\
\text { age, } \\
\text { months }\end{array}$ & Group & Head & Torso & Forelimbs & Hind limbs & Skin & Liver & Heart & Lungs & Kidneys & $\begin{array}{l}\text { Gastrointestinal } \\
\text { tract }\end{array}$ \\
\hline \multirow{3}{*}{2} & control & $1.23 \pm 0.02$ & $0.38 \pm 0.03$ & $0.27 \pm 0.01$ & $0.31 \pm 0.01$ & $0.31 \pm 0.02$ & $0.43 \pm 0.05$ & $0.03 \pm 0.02$ & $0.09 \pm 0.02$ & $0.01 \pm 0.02$ & $0.2 \pm 0.08$ \\
\hline & experimental 1 & $1.37 \pm 0.01$ & $0.42 \pm 0.04$ & $0.32 \pm 0.01$ & $0.37 \pm 0.02$ & $0.36 \pm 0.03$ & $0.46 \pm 0.03$ & \begin{tabular}{|l|}
$0.04 \pm 0.01$ \\
\end{tabular} & $0.12 \pm 0.01$ & $0.06 \pm 0.01$ & $0.5 \pm 0.04$ \\
\hline & experimental 2 & $1.53 \pm 0.04$ & $0.48 \pm 0.02$ & $0.43 \pm 0.02$ & $0.41 \pm 0.02$ & $0.40 \pm 0.04$ & $0.51 \pm 0.02$ & $0.06 \pm 0.04$ & $0.16 \pm 0.01$ & $0.08 \pm 0.03$ & $0.8 \pm 0.06$ \\
\hline \multirow{3}{*}{3} & control & $39.18 \pm 0.12$ & $10.19 \pm 0.37$ & $10.08 \pm 0.28$ & $13.38 \pm 0.19$ & $8.26 \pm 0.43$ & $15.2 \pm 0.61$ & $2.84 \pm 0.02$ & $6.28 \pm 0.42$ & $2.01 \pm 0.05$ & $10.12 \pm 0.18$ \\
\hline & experimental 1 & $42.25 \pm 0.17$ & $11.53 \pm 0.23$ & $11.19 \pm 0.31$ & $14.56 \pm 0.27$ & $9.21 \pm 0.61$ & $16.4 \pm 0.59$ & $3.07 \pm 0.05$ & $7.32 \pm 0.41$ & $2.48 \pm 0.08$ & $11.38 \pm 0.21$ \\
\hline & experimental 2 & $45.17 \pm 0.19$ & $12.09 \pm 0.12$ & $13.21 \pm 0.37$ & $15.13 \pm 0.22$ & $9.94 \pm 0.37$ & $17.3 \pm 0.51$ & $3.87 \pm 0.04$ & $8.19 \pm 0.37$ & $2.84 \pm 0.07$ & $12.23 \pm 0.37$ \\
\hline \multirow{3}{*}{4} & control & $311.2 \pm 3.81$ & $461.2 \pm 2.91$ & $65.2 \pm 4.28$ & $87.6 \pm 4.2$ & $41.2 \pm 1.28$ & $49.9 \pm 2.33$ & $10.9 \pm 0.87$ & $53.8 \pm 2.76$ & $15.1 \pm 1.03$ & $100.6 \pm 2.86$ \\
\hline & experimental 1 & $319.5 \pm 3.93$ & $488.4 \pm 2.70$ & $68.8 \pm 5.12$ & $90.5 \pm 3.23$ & $44.3 \pm 1.37$ & $50.8 \pm 2.19$ & $11.7 \pm 0.91$ & $56.4 \pm 2.94$ & $16.2 \pm 0.98$ & $102.4 \pm 2.92$ \\
\hline & experimental 2 & $337.4 \pm 3.44$ & $497.5 \pm 3.42$ & $74.3 \pm 4.09$ & $98.4 \pm 3.76$ & $49.5 \pm 1.22$ & $51.9 \pm 2.24$ & $12.3 \pm 0.83$ & $59.7 \pm 2.68$ & $17.4 \pm 0.90$ & $104.8 \pm 2.66$ \\
\hline \multirow{3}{*}{5} & control & $696.4 \pm 5.87$ & $512.3 \pm 2.77$ & $397.6 \pm 3.51$ & $483.5 \pm 4.83$ & $297.7 \pm 3.23$ & $137.3 \pm 2.11$ & $28.3 \pm 0.89$ & $101.1 \pm 4.78$ & $78.5 \pm 1.21$ & $602.3 \pm 8.37$ \\
\hline & experimental 1 & $718.9 \pm 5.13$ & $541.5 \pm 2.51$ & $443.7 \pm 4.12$ & $519.9 \pm 5.19$ & $318.4 \pm 2.82$ & $158.9 \pm 2.08$ & $30.5 \pm 1.27$ & $119.5 \pm 5.21$ & $82.7 \pm 1.44$ & $658.5 \pm 6.45$ \\
\hline & experimental 2 & $736.2 \pm 5.31$ & $578.1 \pm 2.02$ & $492.4 \pm 4.82$ & $563.5 \pm 4.66$ & $339.8 \pm 3.19$ & $179.4 \pm 2.53$ & $32.7 \pm 1.84$ & $124.9 \pm 5.62$ & $89.6 \pm 1.62$ & $704.6 \pm 6.17$ \\
\hline \multirow{3}{*}{$6^{*}$} & control & $1.41 \pm 0.05$ & $5.28 \pm 0.03$ & $0.52 \pm 0.05$ & $1.02 \pm 0.08$ & $0.76 \pm 0.03$ & $0.27 \pm 0.02$ & $0.16 \pm 0.05$ & $0.21 \pm 0.06$ & $0.97 \pm 0.04$ & $0.8 \pm 0.08$ \\
\hline & experimental 1 & $1.48 \pm 0.02$ & $5.41 \pm 0.06$ & $0.59 \pm 0.01$ & $1.21 \pm 0.04$ & $0.84 \pm 0.04$ & $0.32 \pm 0.06$ & $0.18 \pm 0.06$ & $0.29 \pm 0.08$ & $1.09 \pm 0.06$ & $0.99 \pm 0.07$ \\
\hline & experimental 2 & $1.53 \pm 0.07$ & $5.73 \pm 0.04$ & $0.63 \pm 0.02$ & $1.34 \pm 0.02$ & $0.88 \pm 0.07$ & $0.36 \pm 0.08$ & $0.20 \pm 0.04$ & $0.36 \pm 0.04$ & $1.10 \pm 0.05$ & $1.12 \pm 0.06$ \\
\hline \multirow{3}{*}{7} & control & $1.76 \pm 0.06$ & $7.87 \pm 2.12$ & $1.21 \pm 0.12$ & $2.17 \pm 0.89$ & $2.78 \pm 0.54$ & $0.63 \pm 0.06$ & $0.21 \pm 0.02$ & $0.72 \pm 0.04$ & $1.24 \pm 0.22$ & $1.29 \pm 0.23$ \\
\hline & experimental 1 & $1.83 \pm 0.08$ & $8.03 \pm 2.28$ & $1.47 \pm 0.56$ & $2.43 \pm 0.98$ & $3.01 \pm 0.43$ & $0.79 \pm 0.08$ & $0.28 \pm 0.01$ & $0.78 \pm 0.06$ & $1.28 \pm 0.21$ & $1.26 \pm 0.31$ \\
\hline & experimental 2 & $1.94 \pm 0.09$ & $8.56 \pm 1.87$ & $1.94 \pm 0.41$ & $2.88 \pm 0.84$ & $3.21 \pm 0.56$ & $0.84 \pm 0.04$ & $0.36 \pm 0.02$ & $0.86 \pm 0.02$ & $1.36 \pm 0.23$ & $1.38 \pm 0.28$ \\
\hline \multirow{3}{*}{8} & control & $2.11 \pm 0.36$ & $8.73 \pm 1.87$ & $2.02 \pm 0.77$ & $3.11 \pm 0.99$ & $3.09 \pm 0.94$ & $0.86 \pm 0.23$ & $0.39 \pm 0.03$ & $0.98 \pm 0.16$ & $1.56 \pm 0.02$ & $1.14 \pm 0.31$ \\
\hline & experimental 1 & $2.33 \pm 0.42$ & $8.94 \pm 1.94$ & $2.39 \pm 0.69$ & $3.39 \pm 1.02$ & $3.28 \pm 0.76$ & $0.94 \pm 0.27$ & $0.46 \pm 0.04$ & $1.12 \pm 0.19$ & $1.89 \pm 0.06$ & $1.56 \pm 0.36$ \\
\hline & experimental 2 & $2.57 \pm 0.57$ & $9.07 \pm 1.62$ & $2.56 \pm 0.72$ & $3.53 \pm 0.87$ & $3.46 \pm 0.88$ & $1.02 \pm 0.24$ & $0.53 \pm 0.02$ & $1.19 \pm 0.14$ & $1.92 \pm 0.03$ & $1.83 \pm 0.29$ \\
\hline \multirow{3}{*}{9} & control & $2.83 \pm 0.63$ & $11.31 \pm 2.87$ & $2.69 \pm 0.53$ & $3.61 \pm 1.06$ & $3.57 \pm 0.79$ & $1.21 \pm 0.23$ & $0.56 \pm 0.02$ & $1.21 \pm 0.16$ & $2.04 \pm 0.04$ & $2.02 \pm 0.27$ \\
\hline & experimental 1 & $2.94 \pm 0.44$ & $12.47 \pm 2.54$ & $2.78 \pm 0.48$ & $3.72 \pm 1.12$ & $3.69 \pm 0.91$ & $1.37 \pm 0.28$ & $0.59 \pm 0.05$ & $1.27 \pm 0.27$ & $2.06 \pm 0.03$ & $2.13 \pm 0.25$ \\
\hline & experimental 2 & $3.18 \pm 0.49$ & $13.67 \pm 2.19$ & $2.84 \pm 0.63$ & $3.83 \pm 0.87$ & $3.74 \pm 0.88$ & $1.44 \pm 0.37$ & $0.61 \pm 0.03$ & $1.34 \pm 0.23$ & $2.12 \pm 0.02$ & $2.21 \pm 0.32$ \\
\hline
\end{tabular}

* starting at 6 months of age in $\mathrm{kg}$ 